\title{
Artificial photoperiod in pregnant mares and its effect on pregnancy length and postpartum reproductive performance
}

\author{
E. Malschitzky', A. Schilela', Luciana Silva Meirelles', Ana Luiza Gelpi Mattos², R.M. Gregory and R.C.Mattos' \\ 'Reprolab, Departamento de Medicina Animal, Faculdade de Veterinária, UFRGS, Porto Alegre, RS, Brazil \\ ${ }^{2}$ Departamento de Medicina Veterinária, ULBRA, Canoas, RS, Brazil
}

\begin{abstract}
Summary
The aim of the present study was to evaluate the effect of prepartum artificial photoperiod on pregnancy length and reproductive performance in mares. The study included 145 Thoroughbred mares with age between 4 and 23 years. The mares were submitted to a 15 hour light/9 hour dark photoperiod/day $\left(10 \mathrm{~W} / \mathrm{m}^{2}\right)$ during different lengths of time before foaling, constituting the following groups: $<30$ : less than 30 days of artificial photoperiod; 30-45: from 30 to 45 days of artificial photoperiod; 46-60: from 46 to 60 days of artificial photoperiod; $>60$ : more than 60 days of artificial photoperiod. In the moment of delivery, mares were classified according to body condition score (crescent range from 1 to 5) and, when necessary, submitted to surgical repair of the vulva within 30 minutes. Mating occurred when a follicle larger than $40 \mathrm{~mm}$ was detected associated with decrease of uterine edema. Twin pregnancies were reduced manually. The number of days in which mares were submitted to artificial photoperiod influenced significantly the anoestrus rate postpartum $(p=0.033)$, as well as the interval between parturition and the first ovulation $(p=0.019)$. Mares submitted to a larger artificial photoperiod showed anoestrus postpartum rate significantly smaller than that observed in mares submitted to artificial photoperiod of less than 30 days ( $>60-0 \% ;<30-16.7 \%$ ). Parturition-ovulation interval was significantly shorter in mares submitted to artificial photoperiod for more than 30 days $(p<0.001)$. Body condition was influenced by photoperiod. Treatment groups submitted to artificial photoperiod for more than 45 days presented better body condition than that submitted for less than 30 days. The body condition influenced anoestrus postpartum rate $(p=0.07)$ and parturition-ovulation interval $(p=0.073)$. Comparing only mares with body condition score $4(n=81)$, a reduction in parturition-ovulation interval in mares submitted to a longer artificial photoperiod was seen $(p=0.072)$. Pregnancy length was not influenced $(p=0.077)$ by the length of photoperiod. There was no influence either on pregnancy rate in foal heat $(p>0.1)$, or on embryo death rate $(p>0.1)$, or on number of cycles per pregnancy rate $(p=0.798)$. It was concluded that the use of a 15-hour light/9 hour dark photoperiod/day $\left(10 \mathrm{~W} / \mathrm{m}^{2}\right)$ during at least 60 days before delivery decreases significantly the incidence of anoestrus postpartum. The use of this photoperiod for more than 30 days decreases parturition-ovulation interval. There is no influence either on pregnancy rate during foal heat, or on embryo death rate, or on number of cycles per pregnancy.
\end{abstract}

Keywords: $\quad$ equine, artificial photoperiod, postpartum, body condition

\section{Einfluss eines künstlichen Lichtregimes auf die Gestationsdauer und den postpartalen Reproduktionserfolg bei Stuten}

Ziel der Studie war eine Überprüfung des möglichen Effektes eines präpartalen künstlichen Lichtregimes auf die Gestationsdaver und den späteren Reproduktionserfolg. Als Tiergut standen 145 Vollblutzuchtstuten im Alter zwischen 4 und 23 Jahren zur Verfügung. Die Probantinnen wurden einem Lichtregime (15h Licht/9h Dunkelheit/d, 10 W/qm) unterschiedlicher Daver in der Endphase der Gravidität unterzogen: <30 d, 30-45 d, 45-60 d und >60 d. Nach der Abfohlung erfolgte eine Klassifizierung der Stuten anhand eines 5-Punkte-Scores und, wenn erforderlich, eine chirurgische Vulvaversorgung. Die erste Anpaarung wurde bei einer klinisch ermittelten Follikelgröße $>40 \mathrm{~mm}$ und zurückgebildetem Uterusödem vorgenommen. Zwillingsträchtigkeiten waren während des Versuchsverlaufs manuell eliminiert worden. Die Expositionsdauer gegenüber dem künstlichen Lichtregime beeinflusste signifikant die postpartale Anöstrusrate $(p=0,019)$ und das anöstrische Intervall bis zur ersten Ovulation ( $p=0,033)$. Die Expositionsdauer war positiv mit derienigen des postpartalen Anöstrus korreliert ( $>60 d=0 \% ;<30 d=16,7 \%)$. Eine Einwirkungsdaver $>30$ d führte zu einem signifikant verkürzten postpartalen anovulatorischen Intervall ( $p>0,001)$. Die Kondition der Stuten wurde ebenfalls von der Länge der Lichtperiode positiv beeinflusst. Patientinnen mit einer Expositionsdauer $>45 \mathrm{~d}$ zeigten deutlich bessere Resultate als diejenigen mit einer Einwirkzeit von $<30$ d. Vergleicht man auschließlich Stuten mit guter körperlicher Verfassung (Score 4, $n=81$ ), so verkürzt sich bei ihnen mit der Daver der künstlichen Lichtexposition das Intervall bis zur ersten postpartalen Ovulation signifikant ( $p=0,072)$. Demgegenüber lag weder ein Einfluss auf die Gestationsdaver $(p=0,798)$, den embryonalen Fühtod ( $p>0,1)$ noch auf die Anzahl der Zyklen bis zur nächsten erfolgreichen Belegung vor $(p=0,798)$. Aus den Resultaten wird geschlossen, dass ein künstliches Lichtregime (15 h Licht/9 hDunkelheit/ d, 10 W/qm) während der letzten 60 Tage vor der Geburt zu einer signifikanten Reduktion der postpartalen anöstrischen Phase führt und eine solche Exposition länger als 30 Tage das Intervall bis zur ersten postpartalen Ovulation verkürzt. Demgegenüber wird die Trächtigkeitsrate in der Fohlenrosse, der embryonale Frühtod und die Anzahl der bis zur erneuten Gravidität benötigten Zyklen nicht beeinflusst.

Schlüsselwörter: Pferd, Lichtregime, postpartal, Kondition

\section{Introduction}

Mares present seasonal polyoestrus. The ovarian activity peak takes place in late springtime and in summer and most mares do not show it during winter. In South America, commercial interests have lead to a constant search for Thoroughbred foals born as early as possible within the official breeding season.
Hormonal events related to parturition stimulate early follicular development and ovulation, even in mares that have not foaled in the physiologic reproductive season (Ginther, 1992). However, some of those mares either do not present ovarian activity after foaling, or they return to inactivity after the first postpartum 
ovulation, an event known as "lactational anoestrus". According to Palmer and Guillaume (1989), when delivery occurs before the physiologic reproductive season, up to $50 \%$ of the mares do not present postpartum ovulation and $25 \%$ of them do not have ovarian activity after the foal heat ovulation. Other authors reported smaller rates of ovarian inactivity, together with a larger time interval between the first and the second postpartum ovulations in mares that foaled during winter, in relation to those that foaled during spring and summer (Loy, 1980; Witowski and Tishner, 1998).

Apparently, anoestrus and changes in the parturition-ovulation interval are influenced mainly by photoperiod and by body condition (Ginther, 1992; Hines et al., 1987), being also affected by handling and specific characteristics of the year (Nagy et al., 1997). A relation between postpartum anoestrus and lactation has not been established yet, making the term "lactational anoestrus" inappropriate (Ginther, 1992; Dael and Hughes, 1993; Nagy, 1997). The use of an artificial photoperiod during the months that precede delivery may reduce the incidence of postpartum anoestrus (Palmer and Driancourt, 1983) and may shorten the parturition-ovulation interval in mares foaling during the first months in the Thoroughbred official breeding season (Witowski and Tishner, 1998). A reduction in pregnancy length in mares submitted to artificial photoperiod has previously been demonstrated (Hodge et al., 1982).

The aim of this study was to evaluate the effect of the artificial photoperiod on pregnancy length, parturition-ovulation interval, and mare reproductive performance during foal heat.

\section{Materials and methods}

The study included 145 pregnant Thoroughbred mares, with ages between 4 and 23 years, kept in semi-extensive handle conditions in the area of Porto Alegre, Southern Brazil, during the 1997 and 1998 breeding seasons. Mares were submitted to a 15 hour light/9 hour dark photoperiod/day with incandescent bulb $\left(10 \mathrm{~W} / \mathrm{m}^{2}\right)$ and were randomly allocated to different treatments, as follows:

$<30$ : less than 30 (0-26) days of artificial photoperiod before parturition $(n=48)$;

30-45: 30 to 45 days of artificial photoperiod before parturition $(n=31)$;

46-60: 46 to 60 days of artificial photoperiod before parturition $(n=35)$;

>60: more than 60 days of artificial photoperiod before parturition $(n=31)$.

All parturitions were assisted and, if necessary, mares were submitted to surgical repair of the vulva within 30 minutes after delivery. Only mares having normal parturition and without any impairment after delivery were included in the study.

At the moment of parturition, mares were classified according to body condition. A modified Henneke's classification was used (Henneke et al., 1983), in which the nine original categories were joined in pairs and the intermediate one, which shows the minimal body conditions for maximal reproductive efficiency, was maintained.

After delivery, mares were kept free, being fed with oat and commercial supplement twice a day. From the $5^{\text {th }}$ day after foaling on, all mares were examined by means of rectal palpation and ultrasound, at intervals no longer than 48 hours, until a preovulatory follicle $(>40 \mathrm{~mm})$ was detected. From that moment on, examinations were performed every 24 hours, until the ideal mating time. After mating, examinations took place every 48 hours and, if no ovulation occurred, mares were mated again. Twelve Thoroughbred proven fertile stallions were used. Pregnancy was diagnosed at 12 days after ovulation, using real-time mode B ultrasound scanner fitted with a $5 \mathrm{MHz}$ linear transducer. When an embryonic vesicle was detected, the mare was examined weekly until day 45 of pregnancy. Twins were reduced manually before day 16 of pregnancy. Embryonic death was considered as having oc-curred when gestation was interrupted between day 12 and day 45 .

Data were analyzed using variance analysis (ANOVA). Pregnancy length (days), pregnancy rate during foal heat, embryonic death rate, parturition-ovulation interval and incidence of postpartum anoestrus were considered as dependent variables. Duration of the photoperiod, month of parturition, age and body condition were considered as independent variables. General linear model (GLM) was used and, for comparing mean values, Tukey's test was used $(p=0.05)$. Pregnancy and embryonic death rates and incidence of postpartum anoestrus were compared using Chi-square. All data were processed using SPSS 6.0 for Windows (1993).

\section{Results}

The length of exposure to artificial photoperiod showed a significant influence on postpartum anoestrus rate $(p=0.033)$, and on interval between delivery and first ovulation $(p=0.019)$. The results of exposing 145 mares to a 15-hour light/9-hour dark period during a different number of days are shown in table 1.

Mares submitted to artificial photoperiod for more than 60 days showed postpartum anoestrus rate significantly smaller than that observed in mares submitted to artificial photoperiod for less than 30 days $(>60=0.0 \%$; $<30=16.7 \%)$. Mares exposed to artificial photoperiod between 30 and 60 days (30-45 and 46-60) did not show significant difference in postpartum anoestrus rate in comparison to mares exposed for less than 30 days, neither to those exposed for more than 60 days.

Parturition-ovulation interval was significantly shorter in mares exposed to artificial photoperiod for more than 30 days $(p<0.019)$ than in those exposed for less than 30 days. Mares exposed to artificial photoperiod for more than 60 days showed a tendency to less variability on the parturition-ovulation interval (>60: $11.1 \pm 1.6 ; 30-45: 12.3 \pm 3.4 ; 46-60: 12.9 \pm 4.8$; $<30: 17.1 \pm 10.1)$.

Pregnancy length was not influenced by the length of exposure (days) to the artificial photoperiod $(p=0.769)$. Most deliveries, regardless the group, occurred in the last two weeks of August and in September (<30: 9.1 $1.1 ; 30-45$ : 8.8 $1.6 ; 46-60$ : $8.7 \pm 1.5 ;>60: 8.6 \pm 0.9)$. There were no significant differences between the groups $(p=0.533)$. Pregnancy length was neither influenced by age $(p=0.257)$, nor by body condition $(p=0.133)$. Duration of photoperiod did not affect $(p>0.1)$ pregnancy rates during the foal heat in the different groups (<30: 65.2\%; 30 45: $42.7 \%$, 46-60: 70.6\%; >60: $53.3 \%)$ or on embryonic 
death rate $(p>0.1)$. Similarly, there was no significant difference $(p=0.798)$ regarding to the number of cycles required for attaining pregnancy $(<30: 1.4 \pm 0.8 ; 30-45: 1.5 \pm 0.7 ; 46-$ 60: $1.5 \pm 0.9 ;>60: 1.33 \pm 0.7)$.

Tab. 1: Thoroughbred mares postpartum reproductive performance after exposure to artificial photoperiod for different number of days

Postpartaler Reproduktionserfolg bei Vollblutstuten nach Anwendung eines künstlichen Lichtregimes unterschiedlicher Einwirkungsdaver

\begin{tabular}{|l|c|c|c|c|}
\hline Performance & \multicolumn{4}{|c|}{ Artificial photoperiod (days) } \\
\hline & $<30$ & $30-45$ & $46-50$ & $>60$ \\
\hline Postpartum Anoestrus (\%) & $16,7^{\mathrm{a}}$ & $12,9^{\mathrm{a}, \mathrm{b}}$ & $2,9^{\mathrm{a}, \mathrm{b}}$ & $0,0^{\mathrm{b}}$ \\
\hline Parturition-ovulation interval (days) & $17,1^{\mathrm{c}}$ & $12,3^{\mathrm{d}}$ & $12,9 \mathrm{~d}$ & $11,1^{\mathrm{d}}$ \\
\hline Foal heat pregnancy (\%) & 65,2 & 42,7 & 70,6 & 53,3 \\
\hline Embryonic death (\%) & 22,9 & 10 & 11,8 & 16,7 \\
\hline Pregnancy length (days) & 338,6 & 387,5 & 340,5 & 340,8 \\
\hline Month of parturition & 9,1 & 8,8 & 8,7 & 8,6 \\
\hline Age (years) & 9,2 & 8,4 & 10,0 & 8,7 \\
\hline Body condition score & $3,6^{\mathrm{e}}$ & $3,9^{\mathrm{e}, \mathrm{f}}$ & $4,2^{\mathrm{f}}$ & $4,2^{\mathrm{f}}$ \\
\hline
\end{tabular}

Different characters $(a, b)$ in the rows indicate significant difference $(p=0,033)$ Different characters $(c, d)$ in the rows indicate significant difference $(p<0,001)$ Different characters $(e, f)$ in the rows indicate significant difference $(p<0,001)$

Body condition was better in mares exposed to artificial photoperiod for longer periods $(46-60 ;>60)$ than in mares of the $<30$ group. Body condition showed a tendency to affect the rate of postpartum anoestrus $(p=0.070)$ and the parturitionovulation interval $(p=0.073)$.

Parturition-ovulation intervals in mares with body condition 4 exposed to artificial photoperiod during different number of days are shown in Table 2.

Tab. 2: Parturition-ovulation intervals in mares with body condition 4 exposed to artificial photoperiod during different number of days

Intervall zwischen Geburt und der ersten postpartalen Ovulation bei Stuten guter Kondition (Score 4) in Abhängigkeit von der Einwirkungsdaver des künstlichen Lichtregimes.

\begin{tabular}{|c|c|c|}
\hline Photoperiod (days) & N & Parturition-ovulation interval (days) \\
\hline$<30$ & 23 & $13,9^{a}$ \\
\hline $30 \tilde{n} 45$ & 19 & $12,5^{a, b}$ \\
\hline $46 n ̃ 60$ & 21 & $12,6^{a, b}$ \\
\hline$>60$ & 18 & $10,83^{b}$ \\
\hline
\end{tabular}

Different characters $(a, b)$ indicate significant difference $(p<0,072)$

Analyzing only mares with body condition 4, it was observed that those exposed to artificial photoperiod for a longer period $(>60)$ tended to present a shorter parturition-ovulation interval (Table 2), similar to the tendency observed when considering all the mares (Table 1).

\section{Discussion}

The time of the year when delivery occurs may affect the postpartum anoestrus and the duration of the postpartum ovulation interval (Loy, 1980). Postpartum anoestrus and delays on postpartum ovulation occur more frequently in the beginning of the breeding season, namely, during winter days. Possibly these conditions are due to a combined effect of low luminosity, reduced body condition, age and lactation stress (Dael and Hughes, 1993; Nagy et al, 1997). The incidence of the above mentioned postpartum complications may be decreased by using an artificial photoperiod for pregnant mares (Hodge et al, 1982; Palmer and Driancourt, 1983; Witkowski andTishner, 1998). The group of mares exposed to less than 30 days of artificial photoperiod presented an anoestrus rate of $16.7 \%$, significantly superior to that observed in the group exposed for 60 days or more, where no anoestrus was observed. Our results are in agreement with those reported by Palmer and Driancourt (1984), and suggest that pregnant mares should be exposed to a controlled photoperiod of minimum 60 days before the expected delivery date, to avoid the postpartum anoestrus. It is important to mention that, in the present study, basically all deliveries occurred within the same season, eliminating the risk of a negative effect of the natural photoperiod on any of the experimental groups. A significantly shorter postovulation interval was observed in mares exposed for more than 30 days to an artificial photoperiod than in those animals exposed for less than 30 days. Similarly, Witkowski and Tishner (1998) observed a shortening of the period between parturition and ovulation in the foal heat when mares were submitted to an artificial photoperiod. However, Hodge et al. (1982) only observed an effect of the artificial photoperiod after the $2^{\text {nd }}$ postpartum cycle. The last authors detected significantly higher luteinizing hormone (LH) levels on the 7 days before ovulation in mares exposed to artificial light. In nonpregnant mares, the amount of $\mathrm{LH}$ at the last range is the decisive factor for the beginning of the breeding season (Sharp and Davis, 1993). It is likely that rising LH levels may also be the decisive factor affecting the reduced incidence of anoestrus in mares treated for more than 45 days, in relation to those submitted to the artificial photoperiod for less than 30 days. Further, one may suggest that the elevated LH level is responsible for the earlier ovulation and less variability in the parturition-ovulation period observed in animals exposed to light for longer periods.

Mares that were maintained for longer periods under artificial photoperiod presented body condition superior at parturition. Both factors affected anestrous and postpartum ovulation interval rates. Body condition may also affect LH levels (Hines et al., 1987). Mares that present a good body condition at delivery show similar LH levels at the $1^{\text {st }}$ and $2^{\text {nd }}$ ovulations, whereas mares that deliver having a poor body condition show higher $\mathrm{LH}$ levels in the second ovulation than in the $1^{\text {st }}$ one, a pattern similar to that presented by barren mares during the transitional phase. Maybe this phenomenon explains the strong effect that the body condition has on the postpartum anoestrus rate and the parturition-ovulation interval. On the other hand, Irvine and Alexander (1994) hypothesized that the low luminosity and poor body condition, together with other extrinsic factors, should lead to enough stress responsible for the production of endorphins, 
which in turn alter $\mathrm{GnRH}$ secretion. The authors consider that the increased amount of light and better body condition lead to less stress and consequently, to higher $\mathrm{GnRH}$ levels (and LH levels).

Studies on the effect of the body condition on the postpartum breeding performance showed that the interval between parturition and $7^{\text {st }}$ ovulation was not affected, whereas the interval between parturition and the $2^{\text {nd }}$ ovulation was significantly delayed in mares that delivered presenting a poor body condition and did not recover well after parturition (Hennecke et al., 1984). It was also shown that even mares that delivered presenting a poor body condition, if they were given an appropriate diet to increase their fat stores after delivery, they show a performance similar to those in good state at parturition and they keep this condition along lactation. In the present study, a postpartum body condition evaluation was not conducted, but all mares were fed to maintain or recover a condition superior to 4. Comparing only those mares that presented corporeal condition 4 at parturition, the reduced parturition-ovulation interval in mares that were submitted to a minimum of 30 days of artificial light was again observed. According to Nagy et al. (1997) in good handling conditions there is a permanent worry to improve and maintain mares at a good body condition after parturition, so that the body condition should not have a major effect on the postpartum breeding performance. In keeping with our results, the authors observed only on slimmer mares an increased postpartum anoestrus and longer parturition-ovulation interval. These observations allow us to suggest that, despite the existence of a combination of factors, in good handling conditions the artificial photoperiod is the strongest factor that affects postpartum anoestrus and length of the period between parturition and $1^{\text {st }}$ ovulation in mares that deliver at the beginning of the official breeding season.

Although Hodge et al. (1982) reported an average reduction of 10 days in gestational length of mares exposed to photoperiod during the last gestational months, gestational length was not affected by the use of the artificial photoperiod in the present study. The findings of the above mentioned group of researchers were also not confirmed by Witkowski and Tishner (1998). On the other hand, no alterations on weight, height, or shinbone circumference were observed among foals born from mares exposed to the artificial photoperiod, compared with foals born from control mares (Hodge et al., 1982). Even considering that our results do not agree with Hodge's group (1982) in regard to gestational length, it is important to emphasize that no evident negative effect exists on foals development, when mares are exposed to an artificial lighting program.

We also did not observe any effect of the exposure to a controlled photoperiod before delivery on foal heat pregnancy rates, embryonic death and number of cycles necessary to attain gestation.

Age, together with body condition and season may affect the rate of postpartum anoestrus (Deal and Hughes, 1993), for this condition occurs more frequently in older mares that deliver during winter. On the other hand, Nagy et al. (1987) observed an increased rate of $2^{\text {nd }}$ ovulation delay and postpartum anoestrus in younger, primiparous mares. However, the authors considered that their results represent a combined effect of age and number of parturitions. In the present work, we did not observe an effect of age on anoestrus rates.
The shorter parturition-ovulation period and the reduced anoestrus rate allows that another gestation may be attained as soon as the official breeding starts, making it possible to keep the annual parturition interval, even for those mares that deliver during winter. Once gestation is not shortened by the treatment, there is no risk that the artificial photoperiod has any negative effect on foal development. This strategy allows maximum breeding performance, with the birth of foals capable to reach best commercial quotations.

In good handling conditions, an artificial photoperiod of 15 hours light/9 hours darkness, starting 46-60 days before the expected delivery date reduces the ovulation-parturition interval and postpartum anoestrus rate, without altering gestational length, foal estrous pregnancy rates or number of cycles necessary for attaining gestation.

\section{Literature}

Daels, P.F. and J.P. Hughes (1993): The abnormal estrous cycle. In: McKinnon, A.O. and J.L. Voss (eds.) Equine Reproduction. Philadelphia, Lea and Febiger, 144-160

Ginther, O.J. (1992): Reproductive Biology of Mare: basic applied aspects Wisconsin, Equiservices

Henneke, D.R.; G.D. Potter and J.L. Kreider (1984): Body condition during pregnancy and lactation and reproductive efficiency of mares. Theriogenology, 21, 897-909

Henneke, D.R.; G.D. Potter; J.L. Kreider and B.F. Yates (1983): Relationship between condition score, physical measurements and fat percentage in mares. Equine vet. J., 5, 371-372

Hines, K.K.; S.L. Hodge, J.L. Kreider, G.D. Potter, and P.G. Harms (1987): Relationship between body condition and levels of serum luteinizing hormone in postpartum mares. Theriogenology, 28, 815-825

Hodge, S.L., J.L.Kreider, G.D. Potter, P.G. Harms, and J.L Fleeger (1982): Influence of photoperiod on pregnant and postpartum mare. Am. J. Vet. Res., 43, 1752-1755

Irvine, C.H.G. and S.L. Alexander (1994): The role of environmental factors in reproduction in the mare. ARS Veterinária, 10, 33-41

Loy, R.G. (1980): Characteristics of postpartum reproduction in mares. Vet. Clin. N. Amer: Large Animal Practice 2, 345-359

Nagy, P., G.Y Huszenica,. J. Juhás, M. Kulcsár, L Solti, J. Reicziegel, and K. Abaváry (1997): Factors influencing ovarian activity and sexual behavior of postpartum mare under farm conditions. Theriogenology, 50, 1109-1119

Palmer, E. and M.A. Driancourt (1983): Some interactions of season of foaling, photoperiod and ovarian activity. Livestock Pord. Sci., 10, 197-210

Palmer, E. and D. Gillaume (1989): Control mechanisms of the seasonal ovarian activity of the mare. Anais do IX Congresso Brasileiro de Reprodução Animal. Belo Horizonte

Sharp, D.C. and S.D. Davis (1993): Vernal Transition. In: McKinnon, A.O. and J.L Voss,. Equine Reproduction, Philadelphia, Lea and Febiger, 133-142.

Wittowski, M. and M. Tishner (1998): Effect of increased daylight during late pregnancy on the postpartum reproductive performance in mares. $7^{\text {th }}$ International Symposium on Equine Reproduction. Pretoria

Prod. Dr. Rodrigo C. Mattos

U.F.R.G.S Faculdade de Veterinaria

AV. Bento Goncalves 9090

Porto Alegre, R. S., Brasilien

Tel: 0055-51-3312327

Fax: 0055-51-3195300

Email:RCMattos@vortex.ufrgs.br 